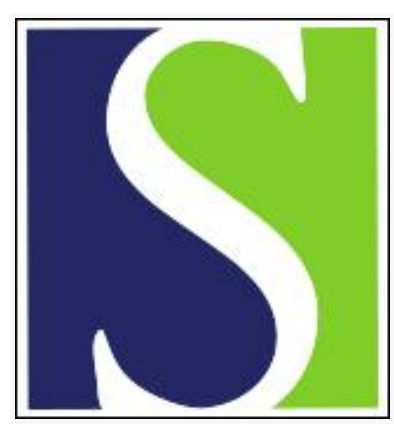

Scand J Work Environ Health 1994;20(5):349-363

https://doi.org/10.5271/sjweh.1386

Issue date: 01 Oct 1994

Association between ambulatory blood pressure and alternative formulations of job strain.

by Landsbergis PA, Schnall PL, Warren K, Pickering TG, Schwartz JE

Affiliation: Cardiovascular and Hypertension Center, New York Hospital-Cornell University Medical College, New York 10021.

The following articles refer to this text: 2013;39(1):112-119;

2013;39(3):276-283; 2013;39(4):351-360; 2014;40(2):109-132;

2015;41(3):312-321; 2016;42(3):228-236; 2018;44(6):601-612

This article in PubMed: www.ncbi.nlm.nih.gov/pubmed/7863299 


\title{
Association between ambulatory blood pressure and alternative formulations of job strain
}

\author{
by Paul A Landsbergis, EdD, ${ }^{1}$ Peter L Schnall, MD, ${ }^{1}$ Katherine Warren, BA, ${ }^{1}$ \\ Thomas G Pickering, MD, ${ }^{1}$ Joseph E Schwartz, $\mathrm{PhD}^{1,2}$
}

\begin{abstract}
LANDSBERGIS PA, SCHNALL PL, WARREN K, PICKERING TG, SCHWARTZ JE. Association between ambulatory blood pressure and alternative formulations of job strain. Scand $J$ Work Environ Health 1994;20:349-63.
\end{abstract}

\begin{abstract}
OBJECTIVEs - The goal of the study was to determine whether alternative formulations of Karasek \& Theorell's job-strain construct are associated with ambulatory blood pressure and the risk of hypertension.

Methons - Full-time male employees $(\mathrm{N}=262)$ in eight worksites completed a casual blood pressure screening, medical examinations, and questionnaires and wore an ambulatory blood pressure monitor for $24 \mathrm{~h}$ on a workday. Cases of hypertension were ascertained from casual blood pressure readings for a case-referent analysis. A cross-sectional analysis was also conducted, ambulatory (continuous) blood pressure measurements being used as the outcome.

RESULTS - All formulations of job strain exhibited significant associations with systolic blood pressure at work and home, but not with diastolic blood pressure. Employees experiencing job strain had a systolic blood pressure that was $6.7 \mathrm{~mm} \mathrm{Hg}(\approx 0.89 \mathrm{kPa})$ higher and a diastolic blood pressure that was $2.7 \mathrm{~mm} \mathrm{Hg}(\approx 0.36 \mathrm{kPa})$ higher at work than other employees, and the odds of hypertension were increased [odds ratio (OR) $2.9,95 \%$ confidence interval $(95 \% \mathrm{CI}) 1.3-6.6$ ]. Using national means for decision latitude and demands to define job strain increased the systolic and diastolic blood pressure associations to $11.5 \mathrm{~mm} \mathrm{Hg}(\approx 1.53 \mathrm{kPa})$ and $4.1 \mathrm{~mm} \mathrm{Hg}(\approx 0.54 \mathrm{kPa})$, respectively. Adding organizational influence to the task-level decision latitude variable produced a stronger association for hypertension with job strain (OR 3.7, 95\% CI 1.6-8.5). Adding social support to the job-strain model also slightly increased the hypertension risk.

Conclusions - The impact of job strain, at least on systolic blood pressure, is consistent and robust across alternative formulations, more restrictive cut points tending to produce stronger effects.
\end{abstract}

KEY TERMS - hypertension, job strain, occupation, social support, stress.

One of the most influential models of the health effects of work-related stress is Karasek \& Theorell's "job strain" model. According to the model, the greatest risk of illness due to stress occurs to workers facing job strain, defined as a combination of high work-load demands and low job-decision latitude or low job control. Over 30 studies have been published on the association between job strain and cardiovascular disease (CVD) or CVD risk factors $(1,2)$. Most have found a positive association between job strain and outcome. Of six cohort studies of CVD (3-8) and two cohort studies of all-cause mortality $(9,10)$, seven found significant positive associations $(3-7$, $9,10)$.

1 Cardiovascular and Hypertension Center, New York Hospital-Cornell University Medical College, New York, New York, United States.

2 Department of Psychiatry and Behavioral Science, State University of New York at Stony Brook, Stony Brook, New York, United States.

Reprint requests to: Dr PA Landsbergis, Post-Doctoral Fellow in Epidemiology, Hypertension Center, Starr Pavilion/ Room 416, Cornell University Medical College, 525 East 68th St, New York, NY 10021, USA.
The association between job strain and blood pressure has also been examined to ascertain a possible biological mechanism linking job strain and CVD. Nine studies (11-19) have examined job strain and casual blood pressure measured in a clinic setting (in which typically only a few readings are taken), but only one found a significant association (17). However, an ambulatory blood pressure monitor has been used in nine job-strain studies $(15,18,20-26)$ since it is both a more reliable (no observer bias and increased number of readings) and a more valid measure of average blood pressure (blood pressure measured during a person's normal daily activities) than casual measurements of blood pressure.

Of the nine ambulatory blood pressure studies, five provided significant positive results $(15,21-23,26)$, while the remaining four provided mixed results $(18$, $20,24,25)$. Six of the nine studies were cross-sectional $(15,18,21,22,25,26)$, and the effect estimates in these studies, for men, ranged from 2.8 to $4 \mathrm{~mm} \mathrm{Hg}(\approx 0.37-0.53 \mathrm{kPa})$ for diastolic blood pressure and from 6 to $12 \mathrm{~mm} \mathrm{Hg}(\approx 0.80-1.60 \mathrm{kPa})$ for systolic blood pressure. The one unequivocal cohort study (23) found significant increases in systolic $(6.0 \mathrm{~mm} \mathrm{Hg} ; \approx 0.80 \mathrm{kPa})$ and diastolic $(3.8 \mathrm{~mm} \mathrm{Hg}$; 
$\approx 0.50 \mathrm{kPa}$ )) blood pressure in subjects facing job strain at both entry into the study and three years later.

Various forms of the independent variable that suggest a robustness to the job-strain concept have been reported in these studies. However, it might be that this is an artifact of the selection process of reporting the forms that have positive associations with outcome and ignoring negative ones. Therefore, the analysis reported in this paper was designed to examine various operationalizations of the job-strain variable and their association with ambulatory blood pressure (measured continuously) and hypertensive status. The results are presented from an ongoing prospective study being conducted in New York City through the Hypertension Center of New York Hospital-Cornell University Medical College (22, 23, 27, 28).

\section{Formulations of job strain}

Combination of demands and decision latitude. Since 1979, the interaction between job demands and job decision latitude which defines job strain has been operationalized primarily in four ways (2). The most common procedure has been to define employees both above the median on demands and below the median on latitude as a "high strain" group (henceforth called the job-strain "quadrant" definition). Such employees can be identified after self-reports of demands and latitude at either the sample medians (figure la) or national medians, or the means are dichotomized (figure $1 b$ ).

Second, a newer approach [used in six studies with positive results (2)], has been to create a continuous independent variable - demands divided by latitude (figure 1c). Since this quotient term is nonlinear and tends to give more weight to latitude (the denominator) than demands, a similar continuous (but linear) formulation has been proposed in which the contributions of low latitude and high demands are equally weighted (figure $1 \mathrm{~d}) .^{3}$

Third, in five studies $(8,12,13,17,29)$, a multiplicative interaction term controlling for main effects (demands $\times$ latitude, controlling for demands and latitude) was used. However, in only two of these studies $(17,29)$ did the interaction term significantly improve the variance explained by the model beyond what could be obtained with only the main effects.

Fourth, exploratory graphic approaches have been used $(29,31)$ to examine interaction effects and thresholds (nonlinear effects). For example, demands

3 In one study (30), a similar formulation was used to isolate $20 \%$ of the sample as "high strain." The "high strain" group was defined as (demands +1$) \times$ (latitude $-1)<-1.2$, where demands and latitude are standardized scores. Tests of this formulation using the current data set produced results similar to those of other formulations in figure 1 , and therefore, for the sake of brevity, they are not presented here. and latitude have been divided into tertiles or quartiles, and the patterns of heart disease risk then examined across the resulting nine (29) or sixteen (31) exposure cells.

Thresholds. If a population threshold exists for the effect of job strain, the proportion of subjects exceeding this threshold will typically vary across nonpopulation-based samples. For example, if only $10 \%$ of a given sample is actually experiencing "high" (biologically relevant) job strain, but $25 \%$ of the sample is classified as "high strain" according to the quadrant definition, misclassification and a dilution of the effect estimate occurs. One approach to explore possible thresholds, or nonlinear or nonmonotonic dose-response curves, is to dichotomize a continuous exposure variable at various points and plot the resulting odds ratios (32). This approach has been applied in the following presentation.

Main effects. Several studies have also examined the main effects of job demands and job decision latitude and found some significant associations (2). As in studies that use multiplicative interaction formulations, studies that use other formulations to model an interaction implicitly (eg, median cut points or quotient terms) need to examine main effects carefully to determine whether the effect attributed to job strain is due solely to one or both main effects, rather than synergy.

Components of decision latitude. Job decision latitude has traditionally been defined as the combination of skill use and task-level decision-making authority. The two components are often highly correlated $(33,34)$, although not always (31). Therefore, one of these components may be a better predictor of CVD risk. In addition, job decision latitude has traditionally been operationalized as a task-level variable. However, it has been suggested that control not only over task characteristics but over work-group, departmental, or organizational functioning $(35,36)$ may also be important in modifying (buffering) the effect of job demands.

Addition of social support. Workplace social support has also been examined in conjunction with the jobstrain model in several studies of CVD $(7,9,10,29)$, as well as in studies of psychological strain outcomes $(37,38)$. Evidence has been provided for both a main effect of social support $(10,29)$ and a buffering of the effects of job strain by social support $(9,10,29)$. A third approach (7), which does not try to disentangle main effects and interaction, simply hypothesizes that socially isolated (ie, without supportive co-workers or supervisors) "high strain" work ("iso- 
a)

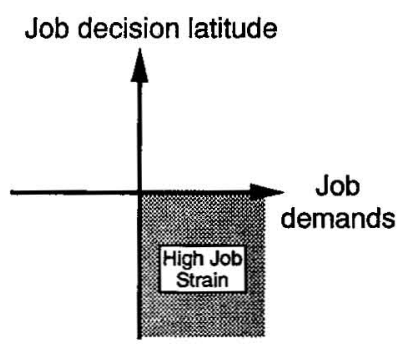

b)

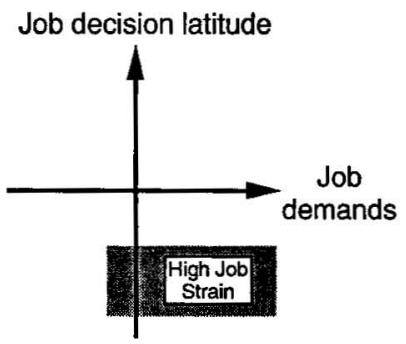

c)

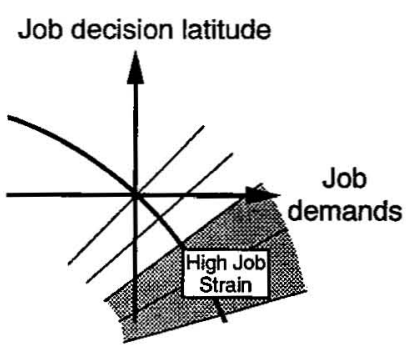

d)

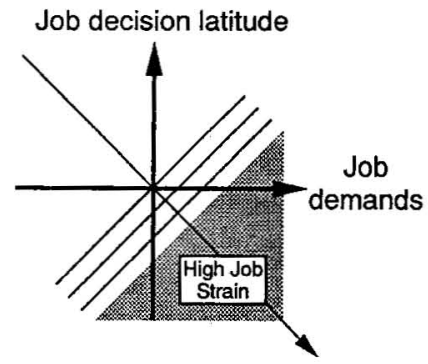

\section{Definitions}

\section{Quadrant term}

Quadrant formed by dichotomizing latitude and demands scores at the medians of the current sample (latitude <37 and demands $>32$ ).

Quadrant term using national means Area formed by using national (U.S. QES) means for latitude and demands (latitude < 33.0 and demands > 30.6 for males; latitude < 30.1 and demands > 31.3 for females).

\section{Quotient term}

Sample demands divided by latitude. This continuous form of the variable can be dichotomized at an arbitrary cutpoint.
Figure 1. Formulations of the job-strain model. (U.S. = United States, QES = Quality of Employment Surveys)

\author{
Linear term \\ Linear function created by $y=(b)$ \\ demands-(c) latitude. (If both variables \\ are on the same scale, $y=(0.5)$ \\ demands-(0.5) latitude.) This con- \\ tinuous form of the variable can be \\ dichotomized at an arbitrary cutpoint.
}

strain" rather than simply "job strain") carries the highest risk. This approach was proposed since "isostrain" is a univariate measure, "a more parsimonious instrument for measuring and analyzing workplace conditions [p 272]" (7).

\section{Socioeconomic status}

The four CVD studies that compared social class groups found stronger associations between job strain and outcome for blue-collar workers $(7,29)$, workers with low education (31), or female clerical workers (3) than for higher socioeconomic status groups. Therefore, potential effect modification by socioeconomic status was examined in the present study.

\section{Hypotheses}

With the preceding as background, this paper focuses on the following seven specific hypotheses: (i) job strain, utilizing a variety of formulations, is associated with higher blood pressure and with increased risk of hypertension; (ii) the main effects of demands and decision latitude are less strongly associated with higher blood pressure or with increased risk of hypertension than formulations of job strain; (iii) the components of decision latitude - skill utilization and decision authority - in combination with demands, are each associated with higher blood pressure and with increased risk of hypertension; (iv) the addition of organizational influence to the task-lev- 
el decision latitude component of the job-strain model increases effect estimates; (v) social support is associated with lower blood pressure and with reduced risk of hypertension; (vi) social support modifies (buffers) the effect of job strain on blood pressure and risk of hypertension [buffering is assessed primarily through multiplicative interaction; an increase in effect estimates when social support is added to the job-strain model (resulting in the "isostrain" model) may result from main effects or buffering], and (vii) higher socioeconomic status modifies (buffers) the effect of job strain on blood pressure and risk of hypertension.

\section{Subjects and methods}

\section{Subjects}

The subject selection and blood pressure measurement have been described in detail elsewhere $(22,27$, 28). Briefly, after an initial casual blood pressure screening at eight New York City worksites, each employing at least 150 men, subjects were eligible to be selected for the initial case-referent study (27, 28 ) if they were male, were between 30 and 60 years of age, were employed more than $30 \mathrm{~h}$ per week, were able to read English, had a body mass index of less than $32.5 \mathrm{~kg} \cdot \mathrm{m}^{-2}$, had no second job of $\geq 15$ $\mathrm{h}$ per week, and had been at their current worksite for at least three years before being approached for this study or before being diagnosed as having high blood pressure, whichever came first. (At the eighth worksite the employment criterion was relaxed to one year.) Subjects were excluded if they had a history of CVD, secondary hypertension, systolic blood pressure greater than $160 \mathrm{~mm} \mathrm{Hg}(\approx 21.28 \mathrm{kPa}]$ or diastolic blood pressure greater than $105 \mathrm{~mm} \mathrm{Hg}$ $(\approx 13.97 \mathrm{kPa})$. Subjects with diagnosed hypertension were eligible only if they could have their medication stopped for at least three weeks before wearing the ambulatory blood pressure monitor and still maintain a diastolic blood pressure below $105 \mathrm{~mm}$ $\mathrm{Hg}(\approx 13.97 \mathrm{kPa})$.

Eligible subjects having both screening and recruitment casual diastolic blood pressure (four to six weeks later) above $85 \mathrm{~mm} \mathrm{Hg}(\approx 11.31 \mathrm{kPa})$ or those taking antihypertensive medication and agreeing to participate were classified as hypertensive and became study cases $(N=85)$. Eligible subjects having screening and recruitment diastolic blood pressures of $\leq 85 \mathrm{~mm} \mathrm{Hg}(\leq 11.31 \mathrm{kPa})$ and agreeing to participate were classified as nonhypertensive and became study referents $(\mathrm{N}=177)$. In addition to the initial case-referent study, a subsequent cross-sectional analysis of this sample was conducted with the ambulatory blood pressure readings as a continuous outcome measure (22). (Subsequent to the cross-sectional analysis, it was discovered that two subjects failed to meet the original eligibility criteria and were dropped from the current analysis.)

\section{Procedures}

The subjects wore an ambulatory blood pressure monitor for $24 \mathrm{~h}$ during a normal workday, using procedures described previously (39). Diary information (ie, whether the subjects reported being at work, at home, or asleep) was used to calculate the average ambulatory blood pressures for each location category. The subjects were also given a routine medical examination, which included a history, a physical examination, blood testing, 24-h urine collection, an electrocardiogram, and an M-mode echocardiogram. In addition, they completed a questionnaire which included the Job Content Questionnaire (JCQ), a 42-item survey based, in part, on questions drawn from the United States (US) Quality of Employment Surveys (QES) (40).

The following job characteristics scales were constructed from the JCQ: Job decision latitude was the sum of two equally weighted subscales: (i) skill utilization, measured by six items (keep learning new things, can develop skills, job requires skill, task variety, repetitious (reverse scored), job requires creativity) and (ii) decision authority, measured by three items (have freedom to make decisions, can choose how to perform work, have a lot of say on the job). Organizational influence was defined as the sum of three items (influence over group decisions, my work group's ideas about company policy will be considered, chances for career development/promotions are good). Composite latitude was the sum of three equally weighted subscales: skill discretion, decision authority, and organizational influence. Psychological job demands were defined by five items (excessive work, conflicting demands, insufficient time to do work, fast work, hard work). Social support at work was the sum of the following two equally weighted subscales: (i) co-worker support, measured by four items (competent co-workers, friendly coworkers, co-workers helpful in getting the job done, co-workers take a personal interest in me) and (ii) supervisor support, measured by four items (supervisor successful in getting people to work together, supervisor helpful in getting the job done, supervisor pays attention to what I am saying, supervisor concerned about welfare of those under him or her). Physical exertion was measured by a single item (job requires lots of physical effort). All of these JCQ items were scored on a Likert scale of 1 to 4 . Decision latitude, psychological demands, and composite latitude were constructed to have a range of 12 to 48. The internal consistency was above 0.70 for all of the scales, except for organizational influence (Cronbach's alpha $=0.62$ ) (table 1).

The following questionnaire scales and items were also analyzed. Type A behavior was evaluated by the 52 -item Jenkins Activity Survey (41). Subjects were classified as "Type A" if their standardized scores were above 0. Demographic items included years of education, race, and age. Race was classified as Caucasian versus other (including His- 
Table 1. Descriptive sample statistics, 262 male employees from eight worksites in New York City.

\begin{tabular}{|c|c|c|c|c|}
\hline & Percentage & Mean & $\begin{array}{l}\text { Standard } \\
\text { deviation }\end{array}$ & $\begin{array}{l}\text { Cronbach's } \\
\text { alpha }\end{array}$ \\
\hline Age (years) & . & 44.3 & 8.6 & . \\
\hline Education & . & 14.4 & 2.5 & . \\
\hline Body mass index $\left(\mathrm{kg} \cdot \mathrm{m}^{-2}\right)$ & . & 25.9 & 2.9 & . \\
\hline Urinary sodium (ME $\mathrm{q} \cdot 24 \mathrm{~h}^{-1}$ ) & . & 149.0 & 64.3 & . \\
\hline Work-load demands & . & 31.7 & 6.3 & 0.74 \\
\hline $\begin{array}{l}\text { Decision latitude } \\
\text { Den }\end{array}$ & . & 35.9 & 6.0 & 0.83 \\
\hline Skill discretion & . & 17.7 & 2.8 & 0.75 \\
\hline Decision authority & . & 18.2 & 3.8 & 0.77 \\
\hline Organizational influence & . & 14.9 & 4.2 & 0.62 \\
\hline Composite latitude & . & 33.9 & 5.9 & 0.82 \\
\hline Social support & . & 22.8 & 3.6 & 0.82 \\
\hline Supervisor support & . & 11.0 & 2.5 & 0.92 \\
\hline Co-worker support & - & 11.7 & 1.6 & 0.71 \\
\hline Physical exertion & - & 1.9 & 0.8 & . \\
\hline Work systolic blood pressure $\left(\mathrm{mm} \mathrm{Hg}^{\mathrm{a}}\right)$ & - & 131.6 & 14.0 & . \\
\hline Work diastolic blood pressure (mm Hgá) & . & 82.9 & 8.6 & . \\
\hline Home systolic blood pressure (mm Hga & . & 127.8 & 14.0 & . \\
\hline Home diastolic blood pressure $(\mathrm{mm} \mathrm{Hg}$ ) & · & 79.5 & 8.6 & - \\
\hline Race (Caucasian) & 84 & . & . & . \\
\hline Current smoker & 20 & . & . & . \\
\hline Regular alcohol use & 23 & . & . & . \\
\hline Job strain & 21 & . & . & . \\
\hline
\end{tabular}

a $1 \mathrm{~mm} \mathrm{Hg} \approx 0.133 \mathrm{kPa}$.

panics). Alcohol and smoking behavior were assessed by interview at the time of the medical examination. The subjects were classified as nondrinkers if they reported they drank not at all or occasionally or as drinkers if they reported daily consumption or binge drinking. They were classified as smokers if they currently smoked.

\section{Data Analysis}

Ambulatory blood pressure (continuous outcome). The association between various formulations of job strain and ambulatory blood pressure was tested by multiple regression, controlling for known or suspected risk factors (age, education, race, body mass index, smoking, alcohol, 24-h urine sodium excretion, type A behavior, physical exertion) and a potential confounder (worksite). Quadrant terms, quotient terms (demands divided by latitude), continuous linear terms (demands minus latitude), and main effects were assessed from an examination of the regression coefficients. Multiplicative interaction was assessed by removing the product term from the full model with main effects and examining the F-statistic for the change in the squared multiple correlation $\left(\mathrm{R}^{2)}\right.$.

The previously reported $(22,27)$ job-strain quadrant term was computed by dichotomizing demands and latitude at their respective sample medians. Fifty-six subjects ( $21 \%$ of the sample) reported job decision latitude of less than 37 and job demands of greater than 32. A similar proportion of subjects was classified as being under "high strain" (22 and $21 \%$, respectively) when skill or authority of less than 19 was combined with demands of greater than 32 .

The influence of the main effects of demands and decision latitude relative to the job-strain quadrant formulation was tested in a comparison of the change in $\mathrm{R}^{2}$ obtained when the quadrant formulation was added to a model which included both main effects with the change in $\mathrm{R}^{2}$ obtained when both main effects were added to a model which included the quadrant formulation.

An examination of the possible thresholds of the effect of job strain on blood pressure was conducted. First, cut points were chosen which classified a smaller proportion of subjects as being under "high strain" (latitude $<36$ and demands $>32$, latitude $<37$ and demands $>33$, skill or authority $<18$ and demands $>32$ ), including the use of the national US QES averages for men (demands $>30$, latitude $<32$, skill $<18$, and authority $<16$ ). The national average for latitude was far lower than our sample's average; however, the national average for demands was also somewhat lower than our sample's average. Therefore, while using national cut points produced a more restricted definition of "high strain" $(8 \%$ of the sample), some additional subjects with lower demands were classified as being under "high strain" with this method (figure 1b).

Second, the quotient term was dichotomized at varying cut points and the pattern of effect sizes (unstandardized regression coefficients) was examined.

Third, a nine-cell model of job strain was created with tertiles of latitude and demands being used as the cut points (demands $<29,29-34,>34$; latitude $<34,34-38,>38$ ) and the model being tested in an analysis of covariance. The numbers of subjects per cell for low, medium, and high demands, respectively, were 41,25 and 17 for low latitude, 22, 40 and 28 for medium latitude, and 18, 32 and 39 for high latitude.

Three composite latitude quadrant terms were constructed with composite latitude below 35,36 and 37 . 
Combined with demands above 32 , they classified 20,22 , and $28 \%$, respectively, as being under "high strain." Finally, the following three "isostrain" terms were computed: (i) job strain (latitude $<37$ and demands $>32$ ) combined with social support below 23.5 (dichotomized at the median); (ii) composite latitude below 36 , demands above 32 , and social support below 23.5; and (iii) composite latitude below 37 , demands above 32 , and social support below 23.5. These three terms defined 14,15 , and $18 \%$, respectively, as being under high "isostrain."

To examine the effect modification by social support, we dichotomized the social support variable at its median. However, since a large number of subjects ( $13 \%$ of the sample) had the median value, two separate dichotomizations were examined; they defined 40 and $53 \%$ as having low social support. To examine effect modification by education, we compared subjects with a high school diploma or less education (34\% of the sample) with those with some college education or a college degree.

Risk of hypertension (dichotomous outcome). The risk of hypertension (ie, of being a case) was assessed in a test of the defined job-strain formulations with the use of unconditional logistic regression and control for the covariates used for ambulatory blood pressure. The multiplicative interaction was assessed by subtracting the $-2 \log$ likelihood (-2LL) of the saturated model from the model without the interaction term and comparing the result with that of the chi-square distribution. However, instead of the continuous linear term already described (demands-latitude), demands and latitude were first dichotomized and a three-level term was constructed by subtracting latitude from demands.

Missing values. Means were substituted for missing values for several covariates. In addition, missing values for social support for three subjects and for organizational influence for 20 subjects were replaced by worksite-specific means (since these two variables differed significantly by worksite). An analysis with these subjects removed produced similar results.

\section{Results}

\section{Sample characteristics}

Descriptive statistics for the sample of 262 men are shown in table 1 . They averaged 44.3 years of age and 14.4 years of education ( $44 \%$ had at least a fouryear college degree) and were $84 \%$ Caucasian. They also averaged 8.1 years with their current employer. Age, body mass index, alcohol use, and job strain had significant bivariate associations with blood pressure.
Decision latitude and demands were significantly correlated [correlation coefficient $(r)=0.33$, $\mathrm{P}<0.001]$, as were the two subscales of job decision latitude, skill utilization and decision authority $(\mathrm{r}=$ $0.65)$. Job strain was not associated with education (14.3 years of education for "high strain" workers and 14.4 years for other workers). However, job strain was associated with lower social support [21.9 for "high strain" workers and 23.0 for other workers, $t=1.975$, degrees of freedom $(\mathrm{df})=260$, $\mathrm{P}=0.049]$.

\section{Association between job strain and ambulatory blood pressure (continuous outcome)}

The associations between the various formulations of job strain and ambulatory blood pressure are listed in table 2 .

Job-strain quadrant formulation. The $21 \%$ of employees defined as being under "high strain" with the use of the median cut points in this sample (figure 1a) had systolic blood pressure at work that was significantly higher $(6.7 \mathrm{~mm} \mathrm{Hg} ; \approx 0.89 \mathrm{kPa})$ than that of the other employees. Work diastolic blood pressure was also significantly higher for these employees $(2.7 \mathrm{~mm} \mathrm{Hg} ; \approx 0.36 \mathrm{kPa})$.

Other job-strain formulations. The other three formulations (multiplicative interaction, quotient, continuous linear) all exhibited significant associations with work and home systolic blood pressure, although the associations with diastolic blood pressure were not consistently significant.

Main effects. None of the main effects of job demands or job decision latitude on blood pressure were significant at $\mathrm{P}<0.05$, except for job demands and work systolic blood pressure (regression coefficient $=0.40, P=0.015$ ) (data not shown). In addition, adding the previously reported $(22,27)$ quadrant term to a model containing both main effects significantly increased the explained variance for work and home systolic blood pressure $\left(\mathrm{R}^{2}\right.$ change $=0.018, P<0.05$ for both), although the associations with diastolic blood pressure were not significant. In contrast, the increase in explained variance due to adding main effects to a model containing the quadrant term was much smaller and not significant.

Threshold. Choosing cut points that defined 14 and $18 \%$ of the workers as being under "high strain" produced similar associations to the previously reported quadrant term. However, when US national means for latitude and demands were applied (classifying $8 \%$ of the workers as being under "high strain," figure 1b), substantially greater associations with 
Table 2. Associations between formulations of job strain and work and home ambulatory blood pressure (mm $\mathrm{Hg})$ for $262 \mathrm{male}$ employees from eight worksites in New York City (unstandardized regression coefficients). ${ }^{a}$

\begin{tabular}{|c|c|c|c|c|c|c|}
\hline & \multicolumn{2}{|c|}{$\begin{array}{l}\text { Participants } \\
\text { classified as being } \\
\text { under high strain }\end{array}$} & \multicolumn{2}{|c|}{ Work } & \multicolumn{2}{|c|}{ Home } \\
\hline & Number & Proportion & $\begin{array}{l}\text { Ambulatory } \\
\text { systolic } \\
\text { blood } \\
\text { pressure }^{b}\end{array}$ & $\begin{array}{l}\text { Ambulatory } \\
\text { diastolic } \\
\text { blood } \\
\text { pressure }^{b}\end{array}$ & $\begin{array}{l}\text { Ambulatory } \\
\text { systolic } \\
\text { blood } \\
\text { pressure }^{b}\end{array}$ & $\begin{array}{l}\text { Ambulatory } \\
\text { diastolic } \\
\text { blood } \\
\text { pressure }\end{array}$ \\
\hline \multicolumn{7}{|l|}{ Quadrant terms } \\
\hline $\begin{array}{l}\text { Latitude }<37+\text { demands }>32 \\
\text { Latitude }<36+\text { demands }>32 \\
\text { Latitude }<37+\text { demands }>33\end{array}$ & $\begin{array}{l}56 \\
37 \\
47\end{array}$ & $\begin{array}{l}0.21 \\
0.14 \\
0.18\end{array}$ & $\begin{array}{l}6.7^{\star \star} \\
7.4^{\star \star} \\
6.5^{\star \star}\end{array}$ & $\begin{array}{l}2.7^{\star} \\
2.6 \# \\
2.7^{\star}\end{array}$ & $\begin{array}{l}6.5^{\star \star} \\
6.1^{\star} \\
7.6^{\star *}\end{array}$ & $\begin{array}{l}2.4 \# \\
1.5 \\
3.0^{*}\end{array}$ \\
\hline \multicolumn{7}{|l|}{ Quadrant term using national means } \\
\hline Latitude $<32+$ demands $>30$ & 21 & 0.08 & $11.5^{\star \star *}$ & $4.1^{*}$ & $8.6^{\star *}$ & $3.6 \#$ \\
\hline \multicolumn{7}{|l|}{ Multiplicative interaction terms } \\
\hline $\begin{array}{l}\text { Latitude } \times \text { demands } \\
\text { Skill } \times \text { demands } \\
\text { Authority } \times \text { demands } \\
\text { Composite latitude } \times \text { demands }\end{array}$ & $\begin{array}{l}\dot{.} \\
\dot{.}\end{array}$ & $\dot{.}$ & $\begin{array}{l}-0.05^{\star} \\
-0.12^{\star} \\
-0.05 \\
-0.05\end{array}$ & $\begin{array}{r}-0.01 \\
-0.04 \\
0.00 \\
-0.01\end{array}$ & $\begin{array}{l}-0.06^{\star} \\
-0.12^{\star} \\
-0.06 \\
-0.05\end{array}$ & $\begin{array}{l}-0.02 \\
-0.06^{\star} \\
-0.01 \\
-0.02\end{array}$ \\
\hline \multicolumn{7}{|l|}{ Continuous quotient terms } \\
\hline $\begin{array}{l}\text { Demands/latitude (range } 0.41-1.55) \\
\text { Demands } /(2 \times \text { skill) }(\text { range } 0.50-1.55) \\
\text { Demands } /(2 \times \text { authority) } \\
\text { (range } 0.35-2.40) \\
\text { Demands/composite latitude } \\
\text { (range } 0.46-1.85)\end{array}$ & . & $\dot{.} \cdot$ & $\begin{array}{l}10.2^{*} \\
12.9^{\star *} \\
5.7 \# \\
9.0^{\star}\end{array}$ & $\begin{array}{l}4.3 \# \\
6.0^{*} \\
2.1 \\
3.9\end{array}$ & $\begin{array}{l}10.3^{*} \\
13.0^{\star *} \\
5.7^{\#} \\
9.3^{\star}\end{array}$ & $\begin{array}{l}4.3 \# \\
4.7 \# \\
2.5 \\
4.5 \#\end{array}$ \\
\hline \multicolumn{7}{|l|}{ Continuous linear terms } \\
\hline $\begin{array}{l}\text { Demands } / 2-\text { latitude/2 } \\
\text { (range }-7.5-+11.0 \text { ) } \\
\text { Demands } / 2-\text { skill (range }-6.0-+11.0 \text { ) } \\
\text { Demands } / 2-\text { authority } \\
\text { (range }-14.0-+13.5 \text { ) }\end{array}$ & $\dot{.}$ & . & $\begin{array}{l}0.49^{*} \\
0.60^{*} \\
0.32\end{array}$ & $\begin{array}{l}0.20 \\
0.25 \\
0.12\end{array}$ & $\begin{array}{l}0.50^{\star} \\
0.60^{\star} \\
0.34 \#\end{array}$ & $\begin{array}{l}0.18 \\
0.16 \\
0.15\end{array}$ \\
\hline \multicolumn{7}{|l|}{ Components of decision latitude } \\
\hline $\begin{array}{l}\text { Skill }<19+\text { demands }>32 \\
\text { Authority }<19+\text { demands }>32 \\
\text { Skill }<18+\text { demands }>32 \\
\text { Authority }<18+\text { demands }>32\end{array}$ & $\begin{array}{l}57 \\
56 \\
35 \\
30\end{array}$ & $\begin{array}{l}0.22 \\
0.21 \\
0.13 \\
0.12\end{array}$ & $\begin{array}{l}7.3^{\star \star \star} \\
5.3^{\star} \\
10.1^{\star \star \star} \\
7.6^{\star \star}\end{array}$ & $\begin{array}{l}2.5^{\star} \\
2.1^{4} \\
3.1^{\star} \\
3.4^{\star}\end{array}$ & $\begin{array}{l}6.7^{\star \star} \\
5.2^{\star} \\
8.7^{\star \star \star} \\
7.7^{\star \star}\end{array}$ & $\begin{array}{l}1.7 \\
2.0 \\
1.8 \\
3.1^{\star}\end{array}$ \\
\hline \multicolumn{7}{|l|}{$\begin{array}{l}\text { Components of decision latitude using } \\
\text { national means }\end{array}$} \\
\hline $\begin{array}{l}\text { Skill }<18+\text { demands }>30 \\
\text { Authority }<16+\text { demands }>30\end{array}$ & $\begin{array}{l}46 \\
16\end{array}$ & $\begin{array}{l}0.18 \\
0.06\end{array}$ & $\begin{aligned} 7.4^{* *} \\
11.2^{* *}\end{aligned}$ & $\begin{array}{l}2.6 \# \\
2.9\end{array}$ & $\begin{array}{l}6.8^{* *} \\
8.8^{*}\end{array}$ & $\begin{array}{l}1.6 \\
2.2\end{array}$ \\
\hline \multicolumn{7}{|l|}{ Job strain with composite latitude term } \\
\hline $\begin{array}{l}\text { Composite latitude }<35+ \\
\text { demands }>32 \\
\text { Composite latitude }<36+ \\
\text { demands }>32 \\
\text { Composite latitude }<37+ \\
\text { demands }>32\end{array}$ & $\begin{array}{l}52 \\
57 \\
72\end{array}$ & $\begin{array}{l}0.20 \\
0.22 \\
0.28\end{array}$ & $\begin{array}{l}7.9^{\star \star \star} \\
7.8^{\star \star *} \\
6.2^{* * *}\end{array}$ & $\begin{array}{l}3.0^{\star} \\
2.8^{\star} \\
2.4^{\star}\end{array}$ & $\begin{array}{l}7.4^{\star \star \star} \\
8.8^{\star \star \star} \\
6.4^{\star \star}\end{array}$ & $\begin{array}{l}2.5^{\star} \\
2.8^{\star} \\
2.4^{\star}\end{array}$ \\
\hline \multicolumn{7}{|l|}{ Isostrain terms } \\
\hline $\begin{array}{l}\text { Latitude }<37+\text { demands }>32+ \\
\text { support }<23.5 \\
\text { Composite latitude }<36+ \\
\text { demands }>32+\text { support }<23.5 \\
\text { Composite latitude }<37+ \\
\text { demands }>32+\text { support }<23.5\end{array}$ & $\begin{array}{l}37 \\
40 \\
46\end{array}$ & $\begin{array}{l}0.14 \\
0.15 \\
0.18\end{array}$ & $\begin{array}{l}6.8^{* *} \\
6.4^{* *} \\
5.9^{*}\end{array}$ & $\begin{array}{l}3.4^{*} \\
3.3^{*} \\
3.0^{*}\end{array}$ & $\begin{array}{l}6.0^{\star} \\
7.5^{\star \star} \\
5.5^{\star}\end{array}$ & $\begin{array}{l}2.8^{\#} \\
3.5^{\star} \\
2.7^{*}\end{array}$ \\
\hline
\end{tabular}

work blood pressure were observed $[11.5 \mathrm{~mm} \mathrm{Hg}$ $(\approx 1.53 \mathrm{kPa})$ systolic, $4.1 \mathrm{~mm} \mathrm{Hg}(\approx 0.54 \mathrm{kPa})$ diastolic] than previously reported (22).

Dichotomizing the continuous quotient term (demands divided by latitude) at varying cut points along its range (figure 2) suggested a threshold of effect on work blood pressure beginning at about the upper tertile of exposure to job strain in this sample. (Most associations in the upper tertile of exposure were significant, until the number of exposed 


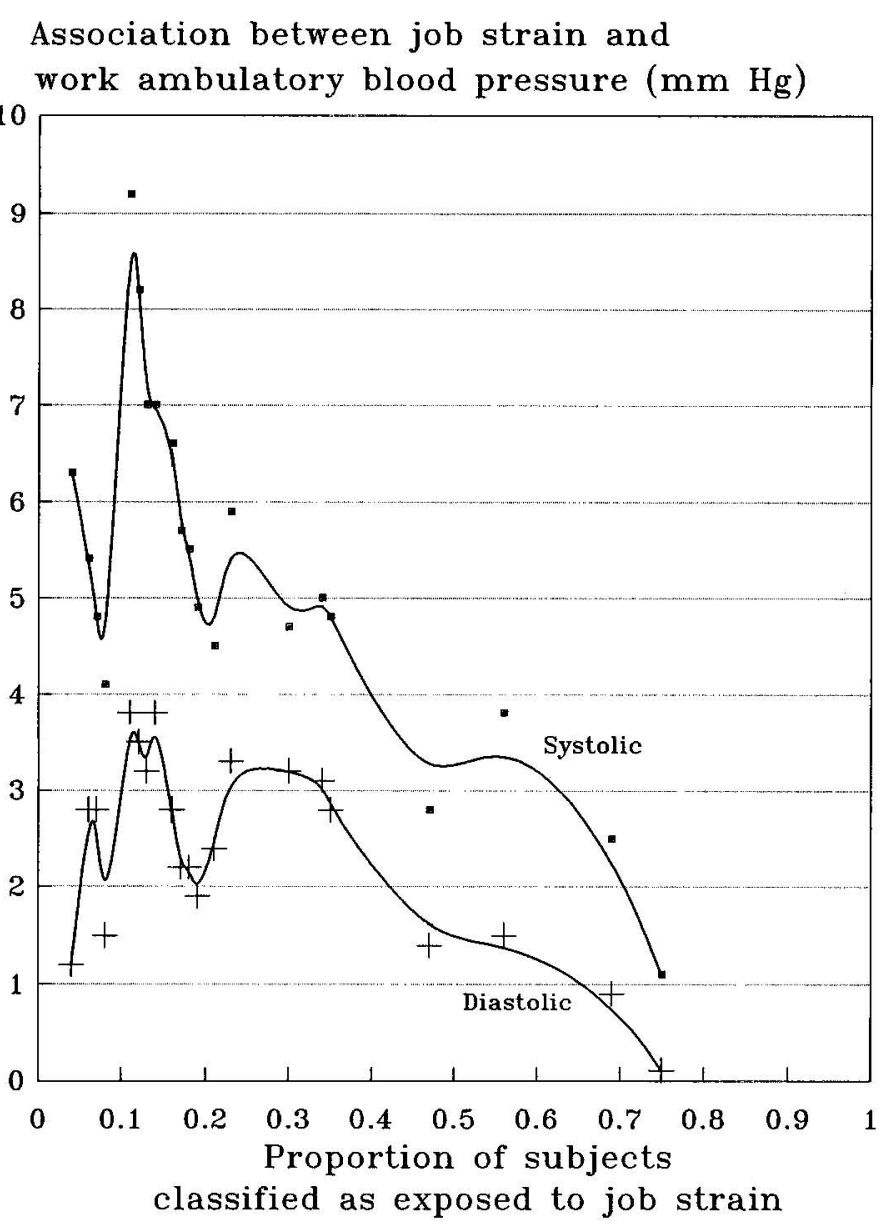

Figure 2. Distribution of associations between exposure to job strain and blood pressure among 262 male employees from eight worksites in New York City after dichotomization of the continuous job-strain variable (demands divided by latitude) at varying cut points. Associations controlled for age, race, education, body mass index, smoking, physical exertion, alcohol, urine sodium, type $\mathrm{A}$, and worksite. (1 $\mathrm{mm} \mathrm{Hg}=\approx 0.133 \mathrm{kPa}$ )

subjects became too small.) Similar patterns were observed for home blood pressure.

Trichotomizing demands and latitude (figures 3 and 4) produced a slightly more complex threshold pattern. While the $6.5 \%$ of the sample in the highest strain cell (high demands plus low latitude) had a work systolic blood pressure of about $9-12 \mathrm{~mm}$ $\mathrm{Hg}(1.20-1.50 \mathrm{kPa})$ higher than those in low demand or high latitude cells, one other cell exhibited marked elevation. Employees with high demands and medium levels of decision latitude exhibited a $4-8 \mathrm{~mm} \mathrm{Hg}(0.53-1.06 \mathrm{kPa})$ elevation. The patterns for diastolic blood pressure were not as clear. While the three highest job-strain cells had a significantly higher diastolic blood pressure than the rest of the sample, some lower strain cells exhibited similar high levels of diastolic blood pressure. The patterns of home blood pressure were similar to those of work blood pressure for this nine-cell model of job strain.
Latitude components. When low skill utilization and low decision authority were each combined with high demands, both were significantly associated with systolic blood pressure, although neither was consistently significantly associated with diastolic blood pressure. Slightly stronger associations were seen for low skill utilization, except when national means were used (table 2).

Composite latitude. Adding the organizational influence subscale to the decision latitude component of the job-strain quadrant term (table 2) resulted in marginally stronger associations with systolic blood pressure, except when a larger proportion (28\%) was defined as exposed to job strain.

Social support. None of the main effects of any social support variable on blood pressure were signif- 


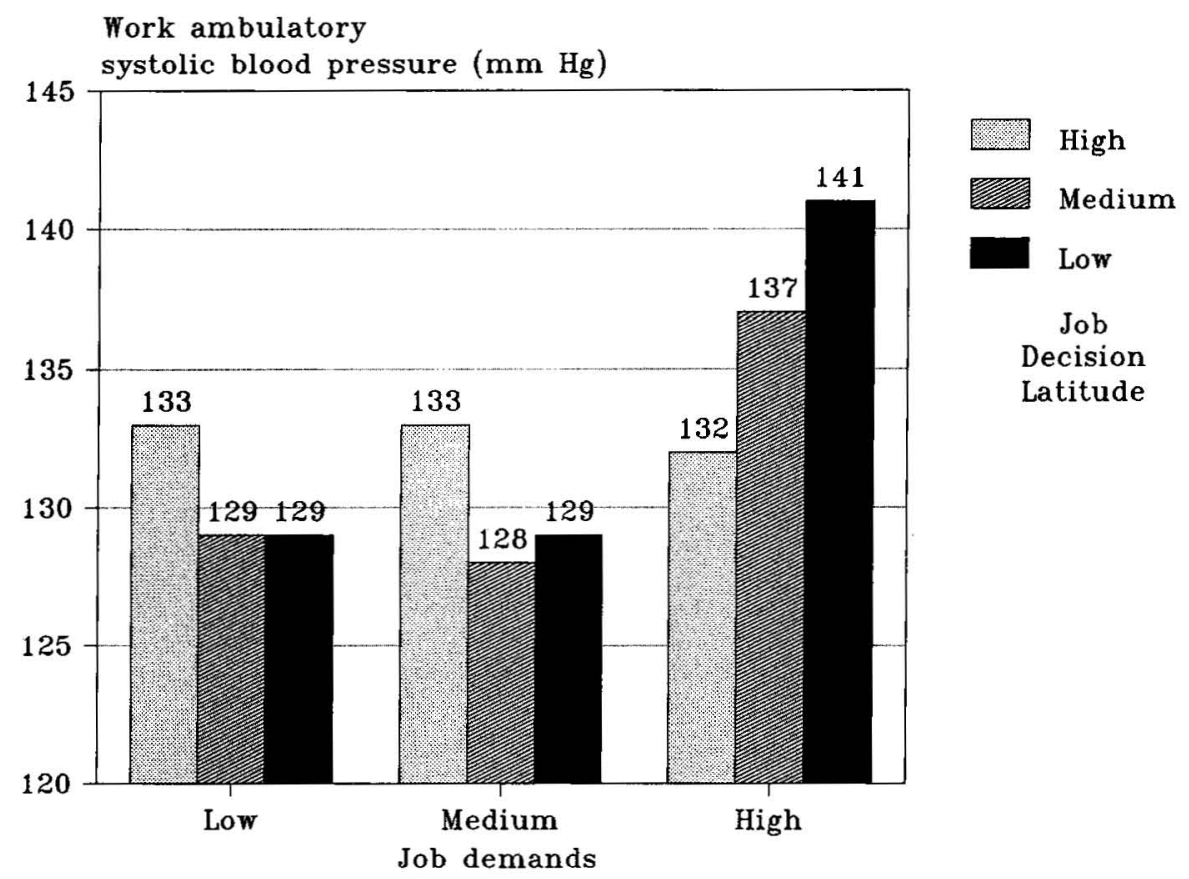

Figure 3. Mean ambulatory systolic blood pressure by tertiles of job demands and job decision latitude among 262 male employees from eight worksites in New York City, by analysis of covariance with control for age, race, education, body mass index, smoking, physical exertion, alcohol, urine sodium, type A, and worksite.

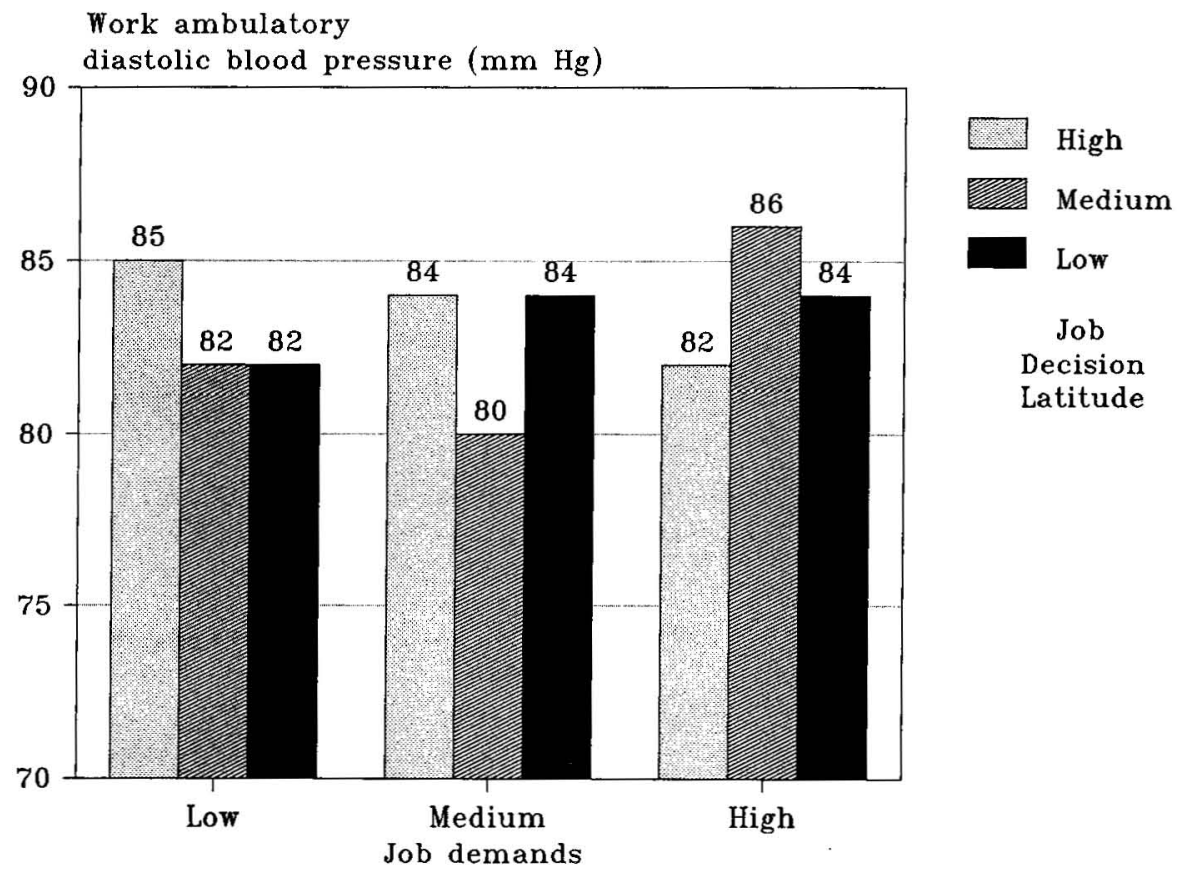

Figure 4. Mean ambulatory diastolic blood pressure by tertiles of job demands and job decision latitude among 262 male employees from eight worksites in New York City, by analysis of covariance with control for age, race, education, body mass index, smoking, physical exertion, alcohol, urine sodium, type A, and worksite. 
Table 3. Associations between job strain and work and home ambulatory blood pressure (mm Hg), stratified by social support and education for 262 male employees from eight worksites in New York City. ${ }^{a}$

\begin{tabular}{|c|c|c|c|c|c|c|}
\hline & \multicolumn{2}{|c|}{$\begin{array}{c}\text { Participants classified } \\
\text { as being under } \\
\text { high strain }\end{array}$} & \multicolumn{2}{|c|}{ Work } & \multicolumn{2}{|c|}{ Home } \\
\hline & Number & Proportion & $\begin{array}{l}\text { Ambulatory } \\
\text { systolic } \\
\text { blood } \\
\text { pressure }^{b}\end{array}$ & $\begin{array}{l}\text { Ambulatory } \\
\text { diastolic } \\
\text { blood } \\
\text { pressure }^{b}\end{array}$ & $\begin{array}{l}\text { Ambulatory } \\
\text { systolic } \\
\text { blood } \\
\text { pressure }^{b}\end{array}$ & $\begin{array}{l}\text { Ambulatory } \\
\text { diastolic } \\
\text { blood } \\
\text { pressure }^{\text {b }}\end{array}$ \\
\hline \multicolumn{7}{|l|}{ Social support } \\
\hline $\begin{array}{l}<23.5(N=140) \\
\geq 23.5(N=122)\end{array}$ & $\begin{array}{l}37 \\
19\end{array}$ & $\begin{array}{l}0.26 \\
0.16\end{array}$ & $\begin{array}{l}7.0^{\star *} \\
5.6\end{array}$ & $\begin{array}{l}3.8^{\star} \\
1.0\end{array}$ & $\begin{array}{l}7.0^{\star} \\
6.5 \#\end{array}$ & $\begin{array}{l}3.8^{\star} \\
0.7\end{array}$ \\
\hline \multicolumn{7}{|l|}{ Social support } \\
\hline $\begin{array}{l}<23(N=105) \\
\geq 23(N=157)\end{array}$ & $\begin{array}{l}27 \\
29\end{array}$ & $\begin{array}{l}0.26 \\
0.18\end{array}$ & $\begin{array}{l}5.1 \\
7.6^{*}\end{array}$ & $\begin{array}{l}3.7 \# \\
1.8\end{array}$ & $\begin{array}{l}4.7^{\star} \\
7.5^{\star *}\end{array}$ & $\begin{array}{l}3.4 \\
2.0\end{array}$ \\
\hline \multicolumn{7}{|l|}{ Education } \\
\hline $\begin{array}{l}\leq 12 \text { years }(N=89) \\
>12 \text { years }(N=173)\end{array}$ & $\begin{array}{l}17 \\
39\end{array}$ & $\begin{array}{l}0.19 \\
0.23\end{array}$ & $\begin{array}{c}10.5^{*} \\
5.0 \#\end{array}$ & $\begin{array}{l}3.9 \\
1.8\end{array}$ & $\begin{array}{l}6.7 \# \\
5.9^{\star}\end{array}$ & $\begin{array}{l}1.6 \\
1.5\end{array}$ \\
\hline
\end{tabular}

icant at $\mathrm{P}<0.05$, whether job strain was included in the model or not (data not shown).

Social support buffering. The association of job strain with diastolic blood pressure was stronger for the subjects with low social support (table 3 ). However, the patterns for systolic blood pressure varied considerably with small changes in the cut point, and the interaction between job strain and social support was not statistically significant. Consistent with the aforementioned finding, each of the "isostrain" measures slightly increased the associations with diastolic blood pressure, but did not increase the associations with systolic blood pressure (table 2).

Socioeconomic status. The association of job strain with work blood pressure was twice as great for the subjects with no more than a high school education than it was for subjects with at least some college education (table 3 ). However, the interaction between job strain and education was not statistically significant. (Education was not significantly associated with blood pressure.)

\section{Association between job strain and hypertensive status (dichotomous outcome)}

Job-strain quadrant formulations. With the median cut-point quadrant term, job strain was associated with significantly increased odds of hypertension [odds ratio (OR) $2.9,95 \%$ confidence interval $(95 \%$ CI) $1.3-6.6$ ] when controlled for the same covariates as in the preceding analysis.
Other job-strain formulations. The quotient term (dichotomized at 1.03 to define also $21 \%$ of the sample as high strain) produced a similar odds ratio (OR $2.8,95 \%$ CI $1.2-6.2$ ) as did the dichotomized linear term. Significant associations with risk of hypertension were also observed for the continuous quotient and linear job-strain terms with the use of decision latitude, as well as those with the use of skill utilization and decision authority.

However, the multiplicative interaction between demands and latitude was not significant (difference in $-2 \mathrm{LL}=0.211, \mathrm{df}=1$ ) when controlled for the two main effects. Since hypertension was defined by casual diastolic blood pressure readings, this finding was consistent with the earlier observation of no multiplicative interaction effect on ambulatory diastolic blood pressure.

Main effects. The risk of hypertension was significantly associated with work-load demands above the median (OR 2.4, 95\% CI 1.1-5.0) and decision latitude below the median (OR 2.1, 95\% CI 1.0-4.4). Along with the nonsignificant multiplicative interaction between demands and latitude, this finding suggests that risk was elevated as a result of the two main effects, rather than interaction. The three-level linear (demands minus latitude) term produced a doubling of the risk (OR 2.2, 95\% CI 1.3-3.6) for each unit change in the variable. Other measures of latitude were associated with slightly reduced risk, but not significantly.

Threshold. Choosing a cut point which defined 18\% as being under "high strain" produced similar asso- 
Figure 5. Distribution of exposure odds ratios for 262 male employees from eight worksites in New York City after dichotomization of the continuous job-strain variable (demands divided by latitude) at varying cut points. The odds ratios controlled for age, race, education, body mass index, smoking, physical exertion, alcohol, urine sodium, type $A$, and worksite.

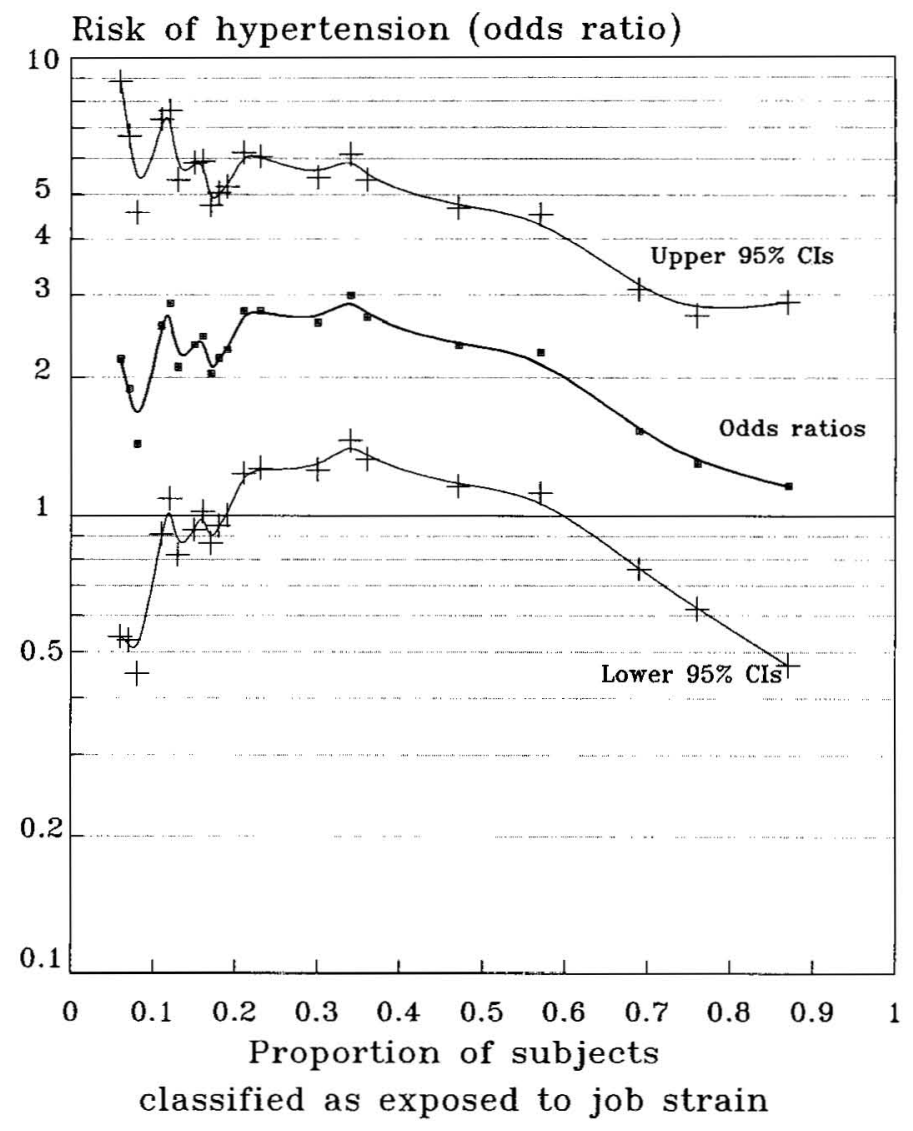

ciations to those of the previously reported quadrant term (OR 2.8, 95\% CI 1.2-6.7). However, quadrant terms using more restrictive cut points, including a term using national means, produced smaller odds ratios, with confidence intervals which included unity.

Dichotomizing the continuous quotient term across its range revealed odds ratios fairly consistently above 2.0 and significant beginning at about the median (figure 5). However, the small number of subjects at the highest cut points (less than 19\% of the sample) produced unstable estimates and confidence intervals that included unity.

Latitude components. The low-authority component of decision latitude in combination with high demands was associated with increased risk of hypertension (OR 2.7, 95\% CI 1.2-6.1). A similar odds ratio was observed for authority when the national means were used; however, the confidence intervals included unity. Low skill utilization (plus high demands) produced smaller and nonsignificant odds ratios with either the sample medians or the national means.

Composite latitude. The composite latitude quadrant terms were associated with risk of hypertension (ta- ble 4), including a term (composite latitude $<36$ and demands $>32$ ) with a substantially stronger association than the previously reported job-strain term (OR 4.0, 95\% CI 1.7-9.2).

Social support. The social support measures were associated with a slightly, but not significantly reduced risk of hypertension (data not shown).

Social support buffering. Strain and social support did not significantly interact (difference in $-2 \mathrm{LL}=$ $0.066, \mathrm{df}=1$ ), and the buffering effects were not consistent, varying at different cut points (table 5). However, the three dichotomous "isostrain" exposure variables were all associated with greater risk than previously reported $(22,27)$ (table 4 ), a finding suggesting a combination of the main effects of job strain and low social support.

Socioeconomic status. The association of job strain with hypertension risk among subjects with only a high school education or less was substantially greater than for the subjects with at least some college education (table 5). However, strain and education did not significantly interact (difference in $-2 \mathrm{LL}=$ 


\section{Acknowledgments}

This research was supported in part by grants HL 18232 and HL 30605 and a National Research Service Award (HL 08578) to Dr P Landsbergis, from the National Heart, Lung and Blood Institute. The authors thank Dr S Schwartz, Dr M Hatch, and Ms S McGarrahan for their valuable comments on an earlier draft of this manuscript.

\section{References}

1. Karasek R, Theorell T. Healthy work. New York, NY: Basic Books, 1990.

2. Schnall PL, Landsbergis PA, Baker D. Job strain and cardiovascular disease. Ann Rev Public Health 1994; $15: 381-411$.

3. LaCroix AZ. High demand/low control work and the incidence of $\mathrm{CHD}$ in the Framingham Cohort [dissertation]. Chapel Hill, NC: University of North Carolina, 1984.

4. Alfredsson L, Spetz CL, Theorell T. Type of occupation and near-future hospitalization for myocardial infarction and some other diagnoses. Int J Epidemiol $1985 ; 14: 378-88$.

5. Haan MN. Job strain and ischaemic heart disease: an epidemiological study of metal workers. Ann Clin Res 1988;20:143-5.

6. Theorell T, Perski A, Orth-Gomer K, Hamsten A, de Faire U. The effect of returning to job strain on cardiac death risk after a first myocardial infarction before age 45. Int J Cardiol 1991;30:61 -7.

7. Johnson JV, Hall EM, Theorell T. Combined effects of job strain and social isolation on cardiovascular disease morbidity and mortality in a random sample of the Swedish male working population. Scand J Work Environ Health 1989;15:271-9.

8. Reed DM, LaCroix AZ, Karasek RA, Miller FD, MacClean CA. Occupational strain and the incidence of coronary heart disease. Am J Epidemiol 1989;129: 495-502.

9. Astrand NE, Hanson BS, Isacson SO. Job demands, job decision latitude, job support, and social network factors as predictors of mortality in a Swedish pulp and paper company. Br J Ind Med 1989;46:334 40.

10. Falk A, Hanson BS, Isacsson S-O, Ostergren P-O. Job strain and mortality in elderly men: social network, support, and influence as buffers. Am J Public Health 1992;82:1136-9.

11. Matthews KA, Cottington EM, Talbott E, Kuller LH, Siegel JM. Stressful work conditions and diastolic blood pressure among blue collar factory workers. Am J Epidemiol 1987;126:280-91.

12. Pieper C, LaCroix AZ, Karasek RA. The relation of psychosocial dimensions of work with coronary heart disease risk factors: a meta-analysis of five United States data bases. Am J Epidemiol 1989;129:483-94.

13. Chapman A, Mandryk JA, Frommer MS, Edye BV, Ferguson DA. Chronic perceived work stress and blood pressure among Australian government employees. Scand J Work Environ Health 1990;16:258 - 69.

14. Netterstrom B, Kristensen TS, Damsgaard MT, Olsen $\mathrm{O}$, Sjol A. Job strain and cardiovascular risk factors: a cross sectional study of employed Danish men and women. Br J Ind Med 1991;48:684-9.

15. Van Egeren LF. The relationship between job strain and blood pressure at work, at home, and during sleep. Psychosom Med 1992;54:337-43.

16. Albright CL, Winkleby MA, Ragland DR, Fisher J, Syme SL. Job strain and prevalence of hypertension in a biracial population or urban bus drivers. Am J Public Health 1992;82:984-9.
17. Haratani T, Kawakami N, Araki S. Job stress and cardiovascular risk factors in a Japanese working population. Presented at the 9th International Symposium on Epidemiology in Occupational Health, Cincinnati, OH, September, 1992.

18. Light KC, Turner JR, Hinderliter AL. Job strain and ambulatory work blood pressure in healthy young men and women. Hypertension 1992;20:214-8.

19. Blumenthal JA, Thyrum ET, Siegel WC. Contribution of job strain, job status and marital status to laboratory and ambulatory blood pressure in patients with mild hypertension. Psychosom Med. In press.

20. Theorell T, Perski A, Åkerstedt T, Sigala F, AhlbergHultén G, Svensson J, et al. Changes in job strain in relation to changes in physiological states: a longitudinal study. Scand J Work Environ Health 1988;14: $189-96$.

21. Theorell T, de Faire U, Johnson J, Hall E, Perski A, Stewart W. Job strain and ambulatory blood pressure profiles. Scand J Work Environ Health 1991;17:3805.

22. Schnall PL, Schwartz JE, Landsbergis PA, Warren K, Pickering TG. The relationship between job strain, alcohol and ambulatory blood pressure. Hypertension 1992;19:488-94.

23. Schnall PL, Schwartz JE, Landsbergis PA, Warren K, Pickering TG. The relationship between job strain and change in ambulatory blood pressure. Presented at the Annual Meeting of the American Public Health Association, San Francisco, CA, 1993.

24. Theorell T, Knox S, Svensson J, Waller D. Blood pressure variations during a working day at age 28 : effects of different types of work and blood pressure level at age 18. J Hum Stress 1985;11:36-41.

25. Härenstam A, Theorell TPG. Work conditions and urinary excretion of catecholamines - a study of prison staff in Sweden. Scand J Work Environ Health 1988; $14: 257-64$.

26. Theorell T, Ahlberg-Hulten G, Jodko M, Sigala F, de la Torre B. Influence of job strain and emotion on blood pressure in female hospital personnel during work hours. Scand J Work Environ Health 1993;19: 313-8.

27. Schnall PL, Pieper C, Schwartz JE, Karasek RA, Schlussel Y, Devereux RB, et al. The relationship between 'job strain,' workplace diastolic blood pressure, and left ventricular mass index: results of a case-control study. JAMA 1990;263:1929-35.

28. Schnall PL, Devereux RB, Pickering TG, Schwartz JE. The relationship between 'job strain,' workplace diastolic blood pressure, and left ventricular mass index: a correction [letter]. JAMA 1992;267:1209.

29. Johnson JV, Hall EM. Job strain, work place social support, and cardiovascular disease: a cross-sectional study of a random sample of the Swedish working population. Am J Public Health 1988;78:1336-42.

30. Karasek RA, Theorell T, Schwartz JE, Schnall PL, Pieper CF, Michela JL. Job characteristics in relation to the prevalence of myocardial infarction in the US Health Examination Survey (HES) and the Health and Nutrition Survey (HANES). Am J Public Health 1988;78:910-18.

31. Karasek RA, Baker D, Marxer F, Ahlbom A, Theorell T. Job decision latitude, job demands, and cardiovascular disease: a prospective study of Swedish men. Am J Public Health 1981;71:694-705.

32. Wartenberg D, Northridge M. Defining exposure in case-control studies: a new approach. Am J Epidemiol 1991;133:1058-71.

33. Karasek RA. Job demands, job decision latitude, and mental strain: implications for job redesign. Adm Sci Q 1979;24:285-308.

34. Schwartz JE, Pieper CF, Karasek RA. A procedure for linking psychosocial job characteristics data to health 
surveys. Am J Public Health 1988;78:904-9.

35. Jackson S. Participation in decision-making as a strategy for reducing job-related strain. J Appl Psychol 1983;68:3-19.

36. Israel BA, Schurman SJ, House JS. Action research on occupational stress: involving workers as researchers. Int J Health Serv 1989;19:135-55.

37. Karasek RA, Triantis KP, Chaudry SS. Coworker and supervisor support as moderators of associations between task characteristics and mental strain. J Occup Behav 1982;3:181-200.

38. Landsbergis PA, Schnall PL, Dietz D, Friedman R, Pickering TG. The patterning of psychological attributes and distress by job strain and social support in a sample of working men. J Behav Med 1992;15: $379-405$.

39. James GD, Yee LS, Harshfield GA, Blank SG, Pickering TG. The influence of happiness, anger, and anx- iety on the blood pressure of borderline hypertensives. Psychosom Med 1986;48:502-8.

40. Karasek RA, Gordon G, Pietrokovsky C, Frese M, Pieper C, Schwartz J, et al. Job content instrument: questionnaire and user's guide. Lowell, MA: University of Massachusetts/Lowell, 1985.

41. Jenkins CD, Rosenman RH, Zyzanski SJ. Prediction of clinical coronary heart disease by a test for the coronary-prone behavior pattern. New Engl J Med 1974; 290:1271-5.

42. Rothman KJ. Modern epidemiology. Boston, MA: Little, Brown and Company, 1986.

43. Schnall PL, Landsbergis PA, Pickering TG, Schwartz JE. Perceived job stress, job strain, and hypertension [letter]. Am J Public Health 1994;84:320-1.

Received for publication: 29 November 1993 